\section{Droperidol inhibits tracheal contraction induced by serotonin, histamine or carbachol in guinea pigs}

Tetsumi Sato MD, ${ }^{*} \ddagger$ Kazuyoshi Hirota MD, $\ddagger$ Akitomo Matsuki MD, $\ddagger$ Elemer K. Zsigmond MD,* Sara F. Rabito MD $\dagger$
Purpose: Droperidol (D) is effective in the treatment of patients with status asthmaticus. It has been reported that $D$ inhibits the bronchoconstriction induced by serotonin (5-HT) but not that by histamine $(H)$ or acetylcholine. However, haloperidol, another butyrophenone, is known to interact with and inhibit calmodulin, an intracellular $\mathrm{Ca}^{++}$-binding protein which is important in the contraction of smooth muscles. The present study was designed to investigate the effects of $D$ on tracheal contractions induced by 5-HT, $H$ or carbachol $(C)$ and to determine the contribution of $\alpha$-adrenoceptors to the relaxant effect of $D$ in vitro.

Methods: Tracheas of female guinea pigs were cut spirally into strips and mounted in water-jacketed organ baths in Tyrode's solution, aerated with a mixture of $95 \% \mathrm{O}_{2}$ and $5 \%$ $\mathrm{CO}_{2}$ at $37^{\circ} \mathrm{C}$. The changes in isometric tension induced by each spasmogen in the strips were measured with a transducer and a polygraph.

Results: We found that $D$ inhibited the tracheal contractions induced by $5-H T, H$ or $C$ in a concentration-dependent manner. At $1.25 \times 10^{-6} \mathrm{M} D$ blocked the effect of $10^{-4} \mathrm{M} \mathrm{5-HT}$ by

\section{Key words}

ANAESTHETICS, INTRAVENOUS: droperidol;

SMOOTH MUSCLE: tracheal;

DRUGS: carbachol, histamine, serotonin.

From the Departments of Anesthesiology, University of Illinois College of Medicine at Chicago*, and Cook County Hospital $\dagger$, Chicago, IL 60612, USA, and University of Hirosaki School of Medicineł. Hirosaki, 036 Japan.

Address correspondence to: Dr. Sara F. Rabito, Department of Anesthesiology and Pain Management, Cook County Hospital, Durand Building, Roøm \#427, 637 South Wood St., Chicago, Illinois 60612, USA.

Phone: (312) 633-7425. Fax: (312) 572-3822.

Accepted for publication 13 th October, 1995.
$44.1 \pm 4.3 \%$ and at $2.5 \times 10^{-6} \mathrm{M}$ by $63.8 \pm 3.8 \%$. Similarly, at $5.0 \times 10^{-6} \mathrm{M}$ concentration, $D$ blocked the effect of $10^{-5} \mathrm{MH}$ by $27.7 \pm 5.3 \%$ and at $10^{-5} M$ by $56.2 \pm 2.6 \%$. Furthermore, 5 $\times 10^{-6} \mathrm{M}$ of $\mathrm{D}$ reduced the contractions produced by $10^{-7} \mathrm{MC}$ by $37.1 \pm 3.0 \%$ and $10^{-5} M$ of $D$ by $76.1 \pm 3.2 \%$. The inhibiting effect of $D$ was strongest on contractions induced by $5-H T$. Prazosin $\left(10^{-6} \mathrm{M}\right)$ affected neither 5-HT-induced contractions nor the inhibition by $D$.

Conclusion: Our data indicate that $D$ partially blocks the contractile responses not only to 5-HT, an effect which would be mediated through a blockade of the 5-HT recepiors, but also to $H$ or $C$, probably through inhibition of calmodulin. Our data support previous reports indicating that droperidol may be an important therapeutic agent in the treatment of patients with hyperreactive airways.

Objectif: Le dropéridol (D) constitue un traitement efficace du status asthmaticus. On a rapporté que $D$ inhibait la bronchoconstriction induile par la sérotonine (5-HT) mais pas celle de l'histamine $(H)$ ou de l'acétylcholine. Cependant on reconnaît que l'halopéridol, une autre butyrophénone, réagit avec la calmoduline et inhibe son action; la calmoduline, une protéine de liaison du $\mathrm{Ca}^{++}$intracellulaire, est importante pour la contraction des muscles lisses. La présente étude vise à étudier les effets de $D$ sur les contractions trachéales induites par 5-HT, $\mathrm{H}$ ou le Carbachol (C) et de déterminer la contribution des récepteurs $\alpha$-adrénergiques sur l'effet relaxant de $D$ in vitro.

Méthode: Des trachées de cobayes femelles ont été découpées en spirales et montées au bain-marie dans une solution de tyrode, aérées avec un mélange de $95 \%$ d' $\mathrm{O}_{2}$ et de $5 \%$ de $\mathrm{CO}_{2}$ à $37^{\circ} \mathrm{C}$. Les changements de tension isométrique induits par chacun des spasmogènes sur les spirales ont été mesurés à l'aide d'un transducteur et d'un polygraphe.

Résultats: Les auteurs ont trouvé que $D$ inhibait les contractions induites par 5-HT, $\mathrm{H}$ et $\mathrm{C}$ proportionnellement aux concentrations. A $1,25 \times 10^{-6} \mathrm{M}, \mathrm{D}$ bloquait l'effet de $10^{-4} \mathrm{M}$ de $5-H T$ par $44 \pm 4,3$ et à $2,5 \times 10^{-6}$ par $63,8 \pm 3,8 \%$. De la même façon, à $5,0 \times 10^{-6} \mathrm{M}, \mathrm{D}$ bloquait l'effet de $10^{-5} \mathrm{MH}$ 
par $27,7 \pm 5,3 \%$ et à $10^{-5}$ par $56,2 \pm 2,6 \%$. De plus, $5 \times 10^{-6}$ $M$ de $D$ diminuait les contractions induites par $10^{-7} M$ de $C$ par $37,1 \pm 3,1 \%$ et $10^{-5} M$ de $D$ par $76,1 \pm 3,2 \%$. L'effet inhibiteur de $D$ érait à son plus fort sur les contractions induites par 5-HT. La prazosine $\left(10^{-6} \mathrm{M}\right)$ n'avait d'effet ni sur les contractions induites par 5-HT ni sur leur inhibition par $D$.

Conclusion: Ces données montrent que D inhibe partiellement les réponses contractiles non seulement au 5-HT, effet d'une médiation probable du bloc des récepteurs 5-HT, mais aussi à $H$ et à $C$, vraisemblablement par inhibition de la calmoduline. Ces données confirment les études antérieures qui rapportent que le dropéridol pourrait être un agent thérapeutique important contre l'hyperréactivité des voies aériennes.

Certain surgical manipulations or procedures associated with the administration of anaesthesia such as tracheal intubation can trigger bronchospasm in patients with hyperreactive airways. Since airway constriction can be a life-threatening event, particularly in the asthmatic patient, the choice of a safe anaesthetic and/or sedative is of paramount importance when caring for these patients.

Bronchial hyperresponsiveness and asthma have become recognized as inflammatory diseases. ${ }^{1,2}$ Histamine, serotonin (5-HT), neuropeptides, prostaglandins and leukotrienes are inflammatory mediators with potent bronchoconstrictor actions which play an important role in the pathogenesis of these diseases. ${ }^{2.3}$ Furthermore, acetylcholine and neuropeptides released from nerve terminals of the parasympathetic nervous system, also cause a variety of symptoms in asthmatic patients. ${ }^{4-7}$

Droperidol is a neuroleptic agent widely used to produce neuroleptanaesthesia and to prevent/treat emesis in many clinical situations. Prezant and Aldrich ${ }^{7}$ reported two patients with status asthmaticus unresponsive to conventional therapy, whose condition improved after receiving droperidol. Gentil et al. ${ }^{8}$ and Takeda et al. ${ }^{9}$ showed that droperidol prevented the bronchospasm induced by 5-HT, but not that induced by histamine or acetylcholine. ${ }^{9}$ In their studies, bronchoconstriction was evaluated by measuring airway conductance, an indirect method to estimate airway calibre which is not considered to be reliable. ${ }^{10}$ However, Otomo et al. " reported that droperidol is also effective in reversing the bronchoconstriction induced by histamine in dogs. These authors utilized an ultrafine fibrescope to evaluate directly the calibre of the airway.

Haloperidol, another butyrophenone derivative, can interact with the activity of calmodulin, an intracellular receptor of $\mathrm{Ca}^{++}$that plays an important role in the contraction of smooth muscles. ${ }^{12}$

The present study was designed to investigate the spasmolytic effects of droperidol on tracheal contractions induced by 5-HT, histamine or carbachol, because these mediators can cause airway constriction in patients with bronchial asthma. We also investigated whether the non-specific $\alpha$-receptor blocking effect of droperidol might be involved in its mechanism of action on airway smooth muscle.

\section{Methods}

\section{Preparation of guinea pig tracheal strips}

This study was approved by our Institutional Animal Care and Use Committee. Female guinea pigs weighing $250-400 \mathrm{~g}$ were sacrificed with an overdose of sodium pentobarbital (Nembutal ${ }^{\circledR}, 75 \mathrm{mg} \cdot \mathrm{kg}^{-1}$, ip). The cervical trachea was removed, isolated free from surrounding connective tissues, and cut spirally into two strips of 3 $\mathrm{mm}$ width and $15 \mathrm{~mm}$ length. All dissecting procedures after removing the trachea were performed in ice-cold Tyrode's solution aerated through with a mixture of $95 \% \mathrm{O}_{2} / 5 \% \mathrm{CO}_{2}$. The composition of Tyrode's solution was (mM): $\mathrm{NaCl} 138, \mathrm{KCL} \mathrm{2.7,} \mathrm{NaH}_{2} \mathrm{PO}_{4} 1.05, \mathrm{MgCl}_{2}$ 1.05, glucose 5.5, $\mathrm{NaHCO}_{3} 5.5$, and $\mathrm{CaCl}_{2}$ 1.8. The tracheal strip was mounted in a $10 \mathrm{ml}$ organ bath filled with Tyrode's solution aerated through with a mixture of $95 \% \mathrm{O}_{2} / 5 \% \mathrm{CO}_{2}$ at $37^{\circ} \mathrm{C}$. Each tracheal strip was fixed with two small clips, one attached to a force displacement transducer (FT 03, Grass Instruments Co, Quincy, MA), connected to a polygraph (Model 79D, Grass Instruments Co, Quincy, MA). Each strip was subjected to a load of $2 \mathrm{~g}$ for at least two hours before the beginning of each experiment. After each experimental step, the strip was washed ten times with Tyrode's solution. At the end of each washing procedure, each strip was subjected to a load of $2 \mathrm{~g}$ and left unstimulated for $20 \mathrm{~min}$ to recover the initial basal tone. Each drug was added to the bath in a volume of $100 \mu \mathrm{l}$. Drug concentrations are expressed as the final concentrations in the bath.

\section{Effect of droperidol on 5-HT-induced tracheal contractions}

After the equilibration phase, tracheal contractions were induced with $10^{-4}$ M 5-HT. Strips where peak responses varied by more than $10 \%$ were excluded from the study. Eight strips were studied in this set. Because the contractions induced by 5-HT are short-lasting, the effect of droperidol was evaluated by adding droperidol before 5 HT. The protocol used was as follows: 
$11^{-4} \mathrm{M}$ 5-HT several times until reproducible contractions were obtained.

$20.05 \%$ ethanol followed by $10^{-4} \mathrm{M} \mathrm{5-HT}$ with a five minute interval.

$31.25 \times 10^{-6} \mathrm{M}$ droperidol dissolved in ethanol followed by $10^{-4} \mathrm{M}$ 5-HT with a five minute interval.

$410^{-4} \mathrm{M}$ 5-HT.

$50.1 \%$ ethanol followed by $10^{-4} \mathrm{M} \mathrm{5-HT}$ with a five minute interval.

$62.5 \times 10^{-6} \mathrm{M}$ droperidol followed by $10^{-4} \mathrm{M} 5-\mathrm{HT}$ with a five minute interval.

The peak tension developed five to ten minutes after the addition of 5-HT to the bath. If the force of contraction in step 4 was $<90 \%$ of that in step 1 , the strip was excluded from the experiment. The mean of the maximal tensions developed in step 1 was taken as the control $100 \%$, the maximal tensions obtained in step 2 and 3 were then compared with the one obtained in step 1 . Likewise, the mean of the maximal tensions developed in step 4 was taken as $100 \%$. The values from step 5 and 6 were compared to the one in step 4 .

\section{Effects of droperidol on histamine- or carbachol- induced tracheal contractions}

Ten tracheal strips were studied with histamine and 11 with carbachol. Because the contractions induced by histamine or carbachol are sustained for more than one hour, the effect of droperidol on the contractions induced by these agonists was evaluated by cumulative additions of droperidol after full contraction by the agonist was attained. In this set we followed this protocol:

I $10^{-5} \mathrm{M}$ histamine or $10^{-7} \mathrm{M}$ carbachol.

$210^{-5} \mathrm{M}$ histamine or $10^{-7} \mathrm{M}$ carbachol and $0.1 \%$ ethanol every ten minutes, up to a total of $0.4 \%$ ethanol concentration, immediately after the peak response to histamine or carbachol was obtained.

$310^{-5} \mathrm{M}$ histamine or $10^{-7} \mathrm{M}$ carbachol and $2.5 \times 10^{-6}$ $M$ droperidol in ten minute intervals, to add up to a total of $10^{-5} \mathrm{M}$, immediately after the peak response to histamine or carbachol was obtained.

\section{The effect of prazosin either on 5-HT-induced} contraction or on the relaxing effect of droperidol In this experimental set, cocaine $(5 \mu \mathrm{M})$ was added to the Tyrode's solution to reduce the reuptake of 5-HT. Ten tracheal strips were studied:

$110^{-4} \mathrm{M} 5$-HT several times until reproducible contractions were obtained.

$210^{-6} \mathrm{M}$ prazosin followed by $10^{-4} \mathrm{M}$ 5-HT with a ten minute interval

$310^{-4}$ M 5-HT.
$41.25 \times 10^{-6}$ droperidol followed by $10^{-4} \mathrm{M} 5$-HT with a five minute interval.

$510^{-4} \mathrm{M}$ 5-HT.

$610^{-6} \mathrm{M}$ prazosin followed by $1.25 \times 10^{-6} \mathrm{M}$ droperidol five minutes later and by $10^{-4} \mathrm{M}$ 5-HT ten minutes later.

The mean of the maximal tensions developed in step 1, 3 , and 5 were used as the basal control values to which the maximal tensions obtained in step 2,4 , and 6 were compared.

\section{Drugs and solutions}

Sodium pentobarbital (Nembutal $\left.{ }^{\circledR}\right)$ was purchased from Abbott Laboratories (North Chicago, IL). Droperidol, 5HT (creatinine sulfate complex), histamine hydrochloride, carbamylcholine (carbachol) and prazosin were purchased from Sigma (St. Louis, MO). Ethanol was purchased from Fisher (Pittsburgh, PA). Cocaine hydrochloride was obtained from the University of Illinois Hospital pharmacy. Other chemicals were obtained from Sigma or Fisher. Twice distilled and deionized water was used for all solutions.

Each drug solution was prepared fresh on the day of the experiment. Droperidol was dissolved in ethanol (Fisher) as a $2.5 \times 10^{-3} \mathrm{M}$ solution and then diluted with Tyrode's solution to the appropriate working concentrations. The final concentrations of ethanol with 1.25 or $2.5 \times 10^{-6} \mathrm{M}$ droperidol in the organ bath were $0.05 \%$ and $0.1 \%$. 5-HT $\left(10^{-2} \mathrm{M}\right)$ was dissolved in distilled water. Histamine and carbachol $\left(10^{-1} \mathrm{M}\right)$ were dissolved in distilled water and then diluted with Tyrode's solution to the appropriate concentrations. Solutions containing droperidol or 5-HT wcre protected from light.

\section{Data analysis}

All results, presented as percentages of the control values, were expressed as mean \pm SEM. The data were analyzed with one way analysis of variance and Bonferroni multiple comparison test. $P<0.01$ was considered to be statistically significant.

\section{Results}

Contractile responses of the tracheal strips to 5-HT, histamine and carbachol

The maximal tracheal tensions developed by the addition of 5-HT, histamine and carbachol were $965 \pm 85$, $855 \pm 60$, and $1010 \pm 100 \mathrm{mg}$, respectively.

\section{Effect of droperidol on 5-HT-induced tracheal} contraction

The previous addition of droperidol, 1.25 and $2.5 \times 10^{-6}$ 


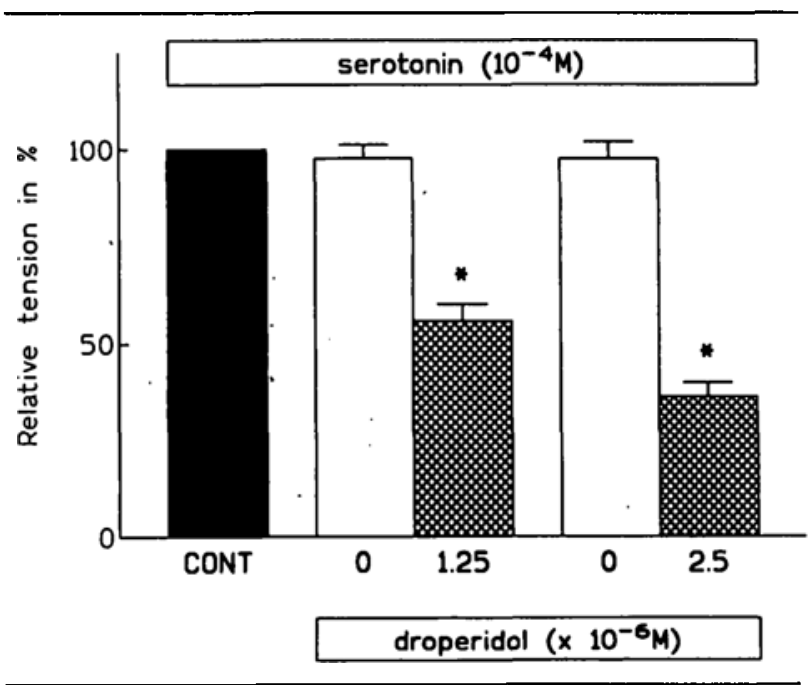

FIGURE 1 Effect of droperidol on serotonin-induced contraction in isolated guinea pig tracheal strips $(n=8)$. Droperidol (reticulated bars) prevented the tracheal contraction induced by $10^{-4} \mathrm{M}$ scrotonin in a concentration-dependent manner. White bars indicate the effects of ethanol $(0.05 \%$ and $0.1 \%)$ used as a solvent of droperidol. Asterisk indicates $P<0.01$ vs control and cthanol.

$\mathrm{M}$, reduced tracheal contractions induced by $10^{-4} \mathrm{M} 5-$ HT by $44.1 \pm 4.3 \%(P<0.001)$ and $63.8 \pm 3.8 \%(P<$ $0.001)$, respectively. Ethanol, in concentrations attained in the bath after adding droperidol, had no significant effect on the contractions (Figure 1).

\section{Effect of droperidol on histamine-induced tracheal contractions}

Droperidol $2.5 \times 10^{-6} \mathrm{M}$, did not affect the contractions induced by $10^{-5} \mathrm{M}$ histamine significantly. However, droperidol at 5.0, 7.5 and $10.0 \times 10^{-6} \mathrm{M}$ concentration reversed the tracheal contraction to $10^{-5} \mathrm{M}$ histamine by $27.7 \pm 5.3 \%(P<0.001), 47.2 \pm 7.4 \%(P<0.001)$, and $56.2 \pm 5.5 \%(P<0.001)$, respectively. Ethanol $(0.1,0.2$, 0.3 , or $0.4 \%$ ) did not alter the tension induced by histamine (Figure 2).

\section{Effect of droperidol on carbachol-induced tracheal contractions}

Droperidol, 2.5, 5.0, 7.5, and $10.0 \times 10^{-6} \mathrm{M}$, reversed the contractions induced by $10^{-7} \mathrm{M}$ carbachol by $12.5 \pm$ $3.0 \%(P<0.01), 37.1 \pm 3.0 \%(P<0.001), 59.3 \pm 3.6 \%$ $(P<0.001)$, and $76.1 \pm 3.2 \%(P<0.001)$, respectively. Ethanol, the solvent of droperidol in concentrations of $0.1,0.2,0.3$, and $0.4 \%$ reduced the carbachol-induced contractions by $7.3 \pm 1.4 \%(P<0.05), 10.2 \pm 1.3 \%(P<$ $0.01), 11.9 \pm 2.2 \%(P<0.001)$, and $9.2 \pm 3.3 \%(P<$ 0.01 ), respectively. However, at concentrations 5-10 $\times$ $10^{-6} \mathrm{M}$ droperidol was more effective than ethanol

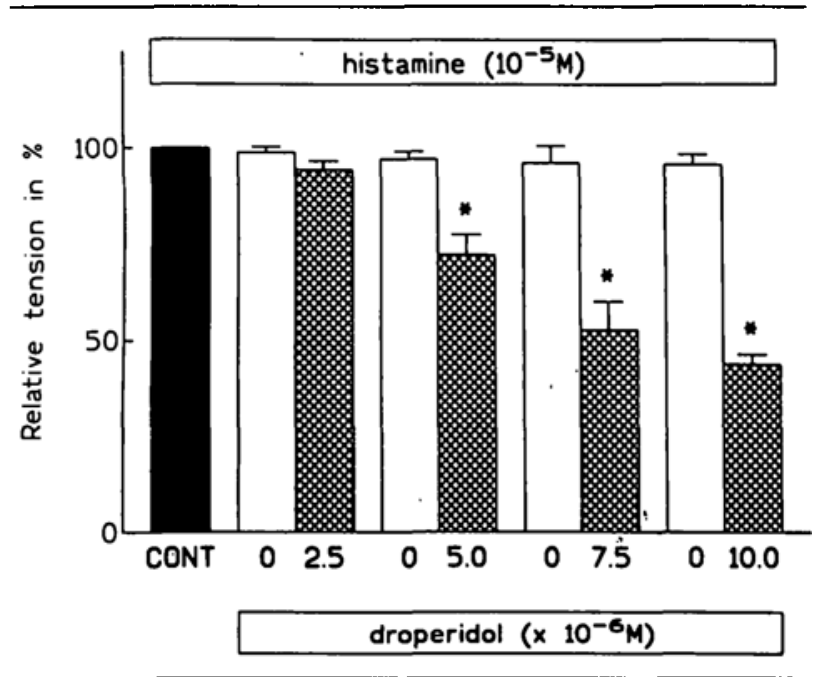

FIGURE 2 Effect of droperidol on histamine-induced contraction in guinea pig isolated tracheal strips $(n=10)$. Droperidol (reticulated bars) reversed the tracheal contraction induced by $10^{-5} \mathrm{M}$ histamine in a concentration-dependent manner. White bars indicate the effects of ethanol $(0.1,0.2,0.3$, and $0.4 \%)$ used as a solvent of droperidol. Asterisk indicates $P<0.01$ vs control and ethanol.

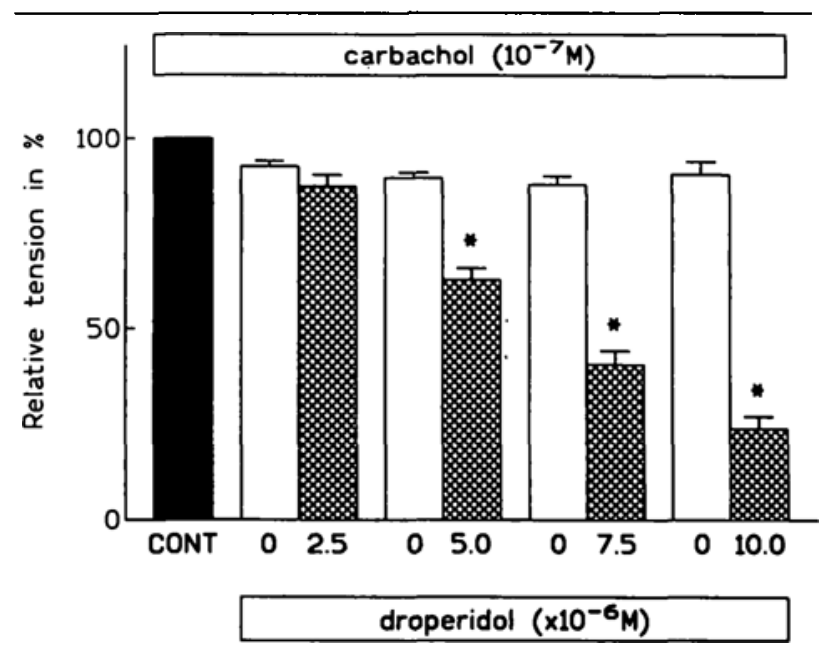

FIGURE 3 Effect of droperidol on carbachol-induced contraction in isolated guinca pig tracheal strips $(n=11)$. Droperidol (reliculated bars) reversed the tracheal contraction induced by $10^{-7} \mathrm{M}$ carbachol in a concentration-dependent manner. Whitc bars indicate the effects of the vehicle ethanol $(0.1,0.2,0.3$, and $0.4 \%)$. Asterisk indicates $P<$ 0.01 vs control and ethanol.

reducing the tracheal contractions induced by carbachol (Figure 3).

Effect of prazosin on either 5-HT-induced contractions or the relaxing effect of droperidol

Prazosin, $10^{-6} \mathrm{M}$, did not alter the contractile response 


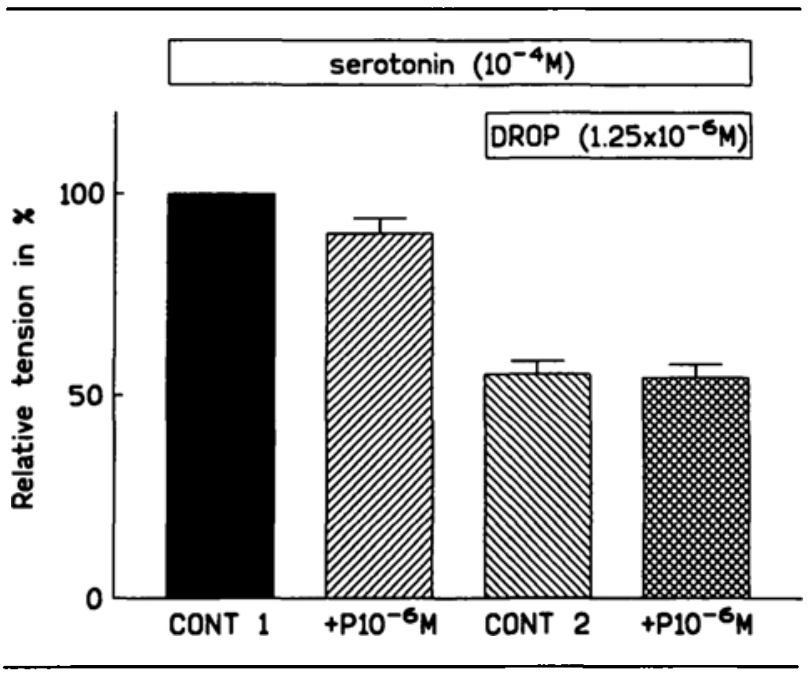

FIGURE 4 The effects of prazosin (P) on serotonin-induced contraction and on the relaxation of the isolated guinea pig tracheal strips by droperidol (DROP) $(n=10) .10^{-6} \mathrm{M}$ prazosin altered neither the response to $10^{-4} \mathrm{M}$ scrotonin nor the effect of $1.25 \times 10^{-6} \mathrm{M}$ droperidol on the contraction induced by serotonin.

to $10^{-4} \mathrm{M}$ 5-HT $(90.2 \pm 3.8 \%, P>0.05)$ (Figure 4$)$. Furthermore, on the contraction induced by $10^{-4} 5-\mathrm{HT}$, $10^{-6} \mathrm{M}$ prazosin did not alter the relaxing effect of 1.25 $\times 10^{-6} \mathrm{M}$ droperidol $(45.3 \pm 3.2 \%$ with prazosin vs 44.4 $\pm 4.4 \%$ without prazosin, $P>0.05$ ).

\section{Discussion}

We report here that droperidol inhibits the contractions of guinea pig tracheal smooth muscle induced not only by 5-HT but also by histamine or carbachol. Prezant $e t$ $a l^{7}$ successfully treated with droperidol two patients with status asthmaticus whose condition had worsened in spite of receiving adequate "conventional" therapy. They speculated that the bronchodilating property of droperidol was the result of its ability to block $\alpha$-adrenergic receptors. On the other hand, Gentil et al. ${ }^{8}$ and Takeda et al. ${ }^{9}$ reported that droperidol prevented the bronchospasm induced in guinea pigs by $5-\mathrm{HT}$, an important inflammatory mediator. It is recognized that droperidol acts as a neuroleptic agent because of its dopaminergic- ${ }^{13}$ and serotonergic- ${ }^{14}$ blocking properties. However, Gentil et al. ${ }^{8}$ found that the prevention of the bronchoconstriction by $5-\mathrm{HT}$ was independent of the effect of droperidol on the autonomic nervous system and strongly suggested a competitive antagonism for droperidol at the level of 5- $\mathrm{HT}_{2}$ receptors. Takeda et al. ${ }^{8}$ also suggested that droperidol reverses both the bronchospasm and the pulmonary vasoconstriction induced by $5-\mathrm{HT}$ at the level of the 5-HT receptor. In addition, in an in vivo model using guinea pigs, Gentil et al. ${ }^{8}$ found that droperidol did not alter the contractile responses to histamine or acetylcholine. However, if droperidol is as effective, as shown for the treatment of severe status asthmaticus, it may have reversed airway contractions induced not only by 5 -HT but also by other spasmogens.

In our study, droperidol inhibited the tracheal contractions not only by 5-HT but also by histamine and carbachol in a concentration-dependent manner. The effect of droperidol in relaxing the trachea was strongest against 5-HT. These results indicate that droperidol can inhibit some common pathways in the signal transduction mechanism of a variety of spasmogens, in addition to its interaction with 5-HT receptors in the airway smooth muscle. For instance, some antipsychotic drugs can inhibit calmodulin, ${ }^{12}$ which plays an important role in the contractile response of smooth muscles as an intracellular receptor of calcium ion and as an activator of myosin light chain kinase. ${ }^{15,16}$ Furthermore, phenothiazine derivatives, which are antipsychotic agents and inhibit calmodulin, also block smooth muscle contractions. ${ }^{17,18}$ Haloperidol, like droperidol, is a butyrophenone derivative that also inhibits calmodulin. ${ }^{13}$ The non-specific effect of droperidol relaxing tracheal contractions induced by 5-HT, histamine and carbachol may be explained by the fact that pharmacological properties of droperidol are similar to that of haloperidol. On the other hand, neuroleptics such as droperidol exert their central nervous system effects by interacting with 5-HT receptors. ${ }^{14}$ Therefore, it was strongly suggested that droperidol prevents 5 -HT-induced contractions by interacting with $5-\mathrm{HT}$ receptors in the airway smooth muscle.

Droperidol has $\alpha$-adrenergic blocking effects ${ }^{19}$ and $\alpha$ adrenoceptors mediate, directly ${ }^{20.21}$ and indirectly, ${ }^{22,23}$ the signal transduction evoked by 5 -HT in smooth muscle cells. Presumably, the droperidol inhibition of the tracheal contractions induced by 5-HT could have been due to blockade of $\alpha$-adrenoceptors. However, our result show that $\alpha$-adrenergic blockade with prazosin does not alter either the 5-HT-induced contraction or the relaxing effect of droperidol. Nonetheless, an $\alpha$-blocking effect of droperidol cannot be excluded as a mechanism of the relaxing effect of droperidol because Barnes et al. have reported that pulmonary $\alpha$-adrenoceptor concentration increased in experimental asthma $\mathrm{a}^{24}$ and that it is higher in the distal segments of the airway. ${ }^{25}$

Since droperidol increases blood catecholamine concentrations, ${ }^{26}$ the bronchodilation by droperidol in vivo could be mediated by an indirect $\beta$-adrenergic stimulation. However, Gentil et al. ${ }^{8}$ showed that pretreatment with propranolol did not alter the beneficial effect of droperidol on 5-HT-induced airway contraction. Our present study in vitro supports their findings.

Droperidol is one of the safest intravenous anaesthetic 
agents used in clinical practice because of its wide therapeutic range and few adverse effects. Furthermore, droperidol, when administered with fentanyl, inhibits histamine release from synovial mast cells. ${ }^{27}$ Therefore, our data as well as the previous reports indicate that droperidol may be an important therapeutic agent in the treatment of patients with hyperreactive airways. In this regard, droperidol (molecular weight: 379.4 ) administered to humans at the dose of $150-200 \mu \mathrm{g} \cdot \mathrm{kg}^{-1}$ resulted in a plasma concentration of around $200 \mathrm{ng} \cdot \mathrm{ml}^{-1}, 26,28 \mathrm{a}$ concentration that is similar to that used in our experiments. However, comparisons of this nature should be taken with caution because isolated, denervated tissue preparations could have increased or decreased sensitivity to agonists or antagonists.

In conclusion, we found that droperidol inhibits tracheal contractions induced by histamine and carbachol as well as those induced by 5-HT in the guinea pig in vitro. Droperidol prevents the tracheal contractions induced by 5-HT probably by interacting with $5-\mathrm{HT}$ receptors in the airway smooth muscle. Our findings also suggest that droperidol might inhibit histamine- and carbachol-induced contractions by interacting with and inhibiting calmodulin.

\section{References}

1 Chung $K F$. Role of inflammation in the hyperreactivity of the airways in asthma (Editorial). Thorax 1986; 41 : 657-62.

2 Djukanovic $R$, Roche WR, Wilson JW, et al. Mucosal inflammation in asthma. American Review of Respiratory Disease 1990: 142: 434-57.

3 Barnes PJ. New concepts in the pathogenesis of bronchial hyperresponsiveness and asthma. J Allergy Clin Immunol 1989; 83: 1013-26.

4 Barnes PJ. Asthma as an axon reflex. Lancet 1986; 1 : 242-4.

5 Boushey HA, Holtzman MJ, Sheller JR, Nadel JA. State of the art. Bronchial hyperreactivity. American Review of Respiratory Disease. 1980; 121: 389-413.

6 Barnes PJ, Minette P, Maclagan J. Muscarinic receptor sybtypes in airways. Trends Pharmacol Sci. 1988; 9: 4I2-6.

7 Prezant DJ, Aldrich TK. Intravenous droperidol for the treatment of status asthmaticus. Crit Care Med 1988; 16 : 96-7.

8 Gentil B, Macquin-Mavier I, Lienhart A, Harf A. Droperidol prevents serotonin-induced bronchospasm in the guinea pig. Anesth Analg 1991; 72: 612-5.

9 Takeda J, Masuda J, Fukushima K. Droperidol prevents serotonin-induced bronchospasm, pulmonary hypertension, and intrapulmonary shunt (Letter). Anesth Analg 1992; 74: 316.
10 Brown RH, Mitzner W, Zerhouni E, Hirshman CA. Direct in vivo visualization of bronchodilation induced by inhalational anesthesia using high-resolution computed tomography. Anesthesiology 1993; 78: 295-300.

11 Otomo N, Hirota $K$, Hashimoto Y, Matsuki A, Zsigmond $E K$, Rabito SF. In vivo relaxant effect of droperidol on bronchoconstriction induced by histamine in dogs. Anesth Analg 1995; 80: S362.

12 Weiss B, Prozialeck WC, Wallace TL. Interaction of drugs with calmodulin. Biochemical, pharmacological and clinical implications. Biochem Pharmacol 1982; 31: 2217-26.

13 Richter JJ. Current theories about the mechanisms of benzodiazepines and neuroleptic drugs. Anesthesiology 1981; 54: 66-72.

14 Leysen JE, Niemegeers CJ, Tollenaere JP, Laduron PM. Serotonergic component of neuroleptic receptors. Nature 1978; 272: 168-71.

15 Brostrom CO. Wolff DJ. Properties and functions of calmodulin. Biochem Pharmacol 1981; 30: 1395-405.

16 Cheung $W Y$. Calmodulin plays a pivotal role in cellular rcgulation. Science 1980; 207: 19-27.

17 Hidaka H, Yamaki T, Totsuka T, Asano M. Selective inhibitors of $\mathrm{Ca}^{2+}$-binding modulator of phosphodiesterase produce vascular relaxation and inhibit actin-myosin interaction. Mol Pharmacol 1979; 15: 49-59.

18 Stull JT, Blumenthal DK, Cooke R. Regulation of contraction by myosin phosphorylation. A comparison between smooth and skeletal muscles. Biochem Pharmacol 1980; 29: 2537-43.

19 Muldoon SM, Janssens WJ, Verbeuren TJ, Vanhoutte PM. Alpha-adrenergic blocking properties of droperidol on isolated blood vessels of the dog. Br J Anaesth 1977; 49: 211-6.

20 Apperley E. Humphrey PPA, Levy GP. Receptors for 5hydroxytryptamine and noradrenaline in rabbit isolated car artery and aorta. Br J Pharmacol 1976; 58: 211-21.

21 Fozard JR. Comparative effects of four migraine prophylactic drugs on an isolated extracranial artery. Eur $\mathrm{J}$ Pharmacol 1976; 36: 127-39.

22 Jester J, Horst WD. Influence of serotonin on adrenergic mechanisms. Biochem Pharmacol 1972; 21 : 333-8.

23 Fozard JR, Mwaluko GMP. Mechanism of the indirect sympathomimetic effect of 5-hydroxytryptamine on the isolatcd heart of the rabbit. Br J Pharmacol 1976; 57: 115-25.

24 Barnes PJ, Dollery CT, MacDermot J. Increased pulmonary $\alpha$-adrenergic and reduced $\beta$-adrenergic receptors in experimental asthma. Nature 1980; 285: 569-71.

25 Barnes PJ, Basbaum CB, Nadel JA. Autoradiographic localization of autonomic receptors in airway smooth muscle. Marked differences betwcen large and small airways. American Review of Respiratory Disease 1983; 127 : 758-62. 
26 Balagny D, Gauzit R, Marty J, Couderc E, Levron JC,

Desmonts $J M$. Effects of droperidol on sympathetic activity and baroreflex control of heart rate in humans.

Anesthesiology 1987; 67: 473-6.

27 Malone DG, Dolan PW. Droperidol-fentanyl inhibits mast cell histamine release in rat synovium, but not skin, after immunologic activation: evidence for mast cell heterogeneity. J Allergy Clin Immunol 1990; 85: 821-7.

28 Fischler $M$, Bonnet $F$, Trang $H$, et al. The pharmacokinetics of droperidol in anesthetized patients. Anesthesiology 1986; 64: 486-9. 